\title{
EDITORIAL
}

\section{A storey of buildings and materials}

\author{
Throughout history, the development of new materials and technologies has enabled more \\ functional and aesthetically pleasing buildings. With the advent of sustainable architecture, \\ the role of materials science in building innovation is becoming more prominent than ever.
}

The London-based office of Nature Reviews Materials is surrounded by warehouses originally built to store the goods transported on the canal network in the 19th and 20th centuries. Having fulfilled their intended purpose for many decades, and with the decline of canal usage and the arrival of nearby King's Cross station, their function needed to change. Some warehouses were converted into offices or houses, others were demolished. This is a natural sequence of events for a fast-developing area of a big city; buildings are rarely demolished because of structural problems, but rather because, with the passage of time, their purpose shifts. With this in mind, it is not surprising that nowadays buildings are designed to last around 50 years, although the materials at our disposal enable much more durable constructions. Clearly, building materials must fulfil some basic requirements in terms of strength, fire resistance and general safety, but these are not the only considerations for architects choosing the materials for new developments. Buildings need to be aesthetically pleasing, practical and comfortable. Moreover, they need to be sustainable - a factor that is increasingly important in an energy-hungry world.

In this issue, we bring together architects, designers and materials scientists to explore the evolving relationship between materials science and architecture. In a Review $^{1}$, Martin Bechthold and James Weaver discuss the

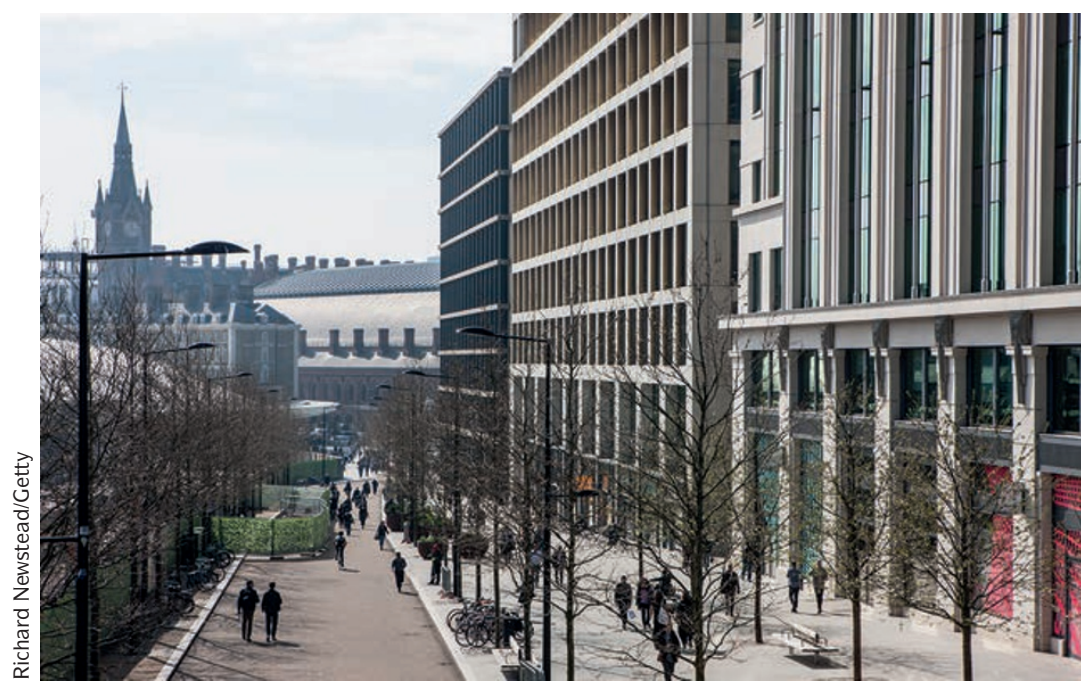

use of different classes of materials in architecture, while Guido Wimmers addresses in a Comment ${ }^{2}$ the use of wood for high-rise buildings. Also in a Comment ${ }^{3}$, Skylar Tibbits and colleagues delve into the design opportunities created by auxetic materials. In our Research Highlight section, we explore two materials advances relevant to the building industry and to sustainable architecture: the development of 3D-printable high-performance steels ${ }^{4}$ and the enhanced efficiency of solar cells based on abundant and non-toxic materials ${ }^{5}$. Finally, the rise of building-integrated solar devices is the topic of a Perspective ${ }^{6}$ by Sergio Brovelli and Francesco Meinardi, summarizing the progress in the optimization of luminescent solar concentrators.

Buildings account for a huge slice of the energy usage in the world: they represent over $40 \%$ of the energy consumption of the EU, USA and China ${ }^{7}$. The contribution of each building to this figure is twofold, being the sum of its embodied energy - the energy needed to build it — and its emissions. The design of new materials and structures can help reduce both types of energy usage. One way to lower the embodied energy is by using new materials, such as concrete with embedded titanium dioxide particles that act as catalysts for reactions that improve air quality by removing nitrogen oxides ${ }^{8}$. Traditional materials can also play a role; for example, wood has a low embodied energy and can sequester carbon. The use of wood for the construction of tall buildings is becoming more and more widespread ${ }^{2}$.

In terms of emissions, sustainable buildings are now a reality. These encompass passive buildings, which minimize the energy needed for heating or cooling, and zero net-energy buildings, which produce all the energy they consume. According to European Union guidelines, all new buildings should be nearly zero-energy by 2020 ; the shift is being considerably aided by advances in materials science. For example, windows can be replaced by transparent materials that harness solar light to generate electricity. Luminescent solar concentrators are already used for this purpose and constitute an exquisite example of architectural integration of solar devices ${ }^{6}$.

New materials and processing techniques also have an important role when shelter needs to be built fast and cheaply, such as in times of humanitarian crises. Active materials that change shape when exposed to 
environmental stimuli, such as heat or moisture, can be shipped in a flat form and then display their pre-programmed shape on-site without the need of assembly, when exposed to the appropriate conditions. Advances in processing techniques, in particular the advent of large-scale additive manufacturing machines, make it possible to $3 \mathrm{D}$ print a concrete house in 24 hours.

Another way in which materials science influences architecture and design is by catalysing innovation and creativity, offering new ways of constructing compelling and attractive buildings and objects. For example, curved-glass facades are now relatively common, as are buildings with kinetic facades that can respond to changes in their environment. With an increasing number of materials that can be 3D printed - transparent glass ${ }^{9}$ and high-performance steels ${ }^{10}$ are very recent additions - the creativity of designers can be truly unleashed. The users' experience is now centre stage, with the advent of garments and furniture that can adapt to the body to enhance comfort and performance ${ }^{3}$.

However, developing better materials is not enough to reach the objective of a more sustainable architecture. The use of fewer materials and a reduction in the combination of different types of materials will make recycling easier when a building is demolished; for example, friction welding of wood enables the components to join without the need for metal screws and adhesives, and nanostructured surfaces can make metal pieces appear coloured without the use of varnish.

Looking forward a century, perhaps our offices near King's Cross will be fulfilling new purposes as self-powered buildings, with negligible environmental impact. The ability to reach this objective is, for the most part, already at our disposal. It is now up to materials scientists, architects and designers to combine their complementary expertise to create marvellous sustainable buildings.

1. Bechthold, M. \& Weaver, J. C. Materials science and architecture Nat. Rev. Mater. 2, 17082 (2017).

2. Wimmers, G. Wood: a construction material for tall buildings. Nat Rev. Mater. 2, 17051 (2017).

3. Papadopoulou, A., Laucks, J. \& Tibbits, S. Auxetic materials in design and architecture. Nat. Rev. Mater. 2, 17078 (2017).

4. Pacchioni, G. 3D printing: may the strength be with you. Nat. Rev. Mater. 2, 17081 (2017).

5. Ashworth, C. Photovoltaics: voltage victory for kesterite solar cells. Nat. Rev. Mater. 2, 17078 (2017).

6. Meinardi, F., Bruni, F. \& Brovelli, S. Luminescent solar concentrators for building-integrated photovoltaics. Nat. Rev. Mater. 2, 17072 (2017).

7. Zhang, Y. et al. China's energy consumption in the building sector: a life cycle approach. Energy Build. 94, 240-251 (2015).

8. Chen, J. \& Poon, C.-S. Photocatalytic construction and building materials: from fundamentals to applications. Build. Environ. 44 1899-1906 (2009).

9. Kotz, F. et al. Three-dimensional printing of transparent fused silica glass. Nature 544, 337-339 (2017).

10. Wang, Y. M. et al. Additively manufactured hierarchical stainless steels with high strength and ductility. Nat. Mater. http://dx.doi. org/10.1038/nmat5021 (2017).

\section{FURTHER INFORMATION}

3D-printed houses: https://all3dp.com/1/3d-printed-house-homes-buildings3d-printing-construction/

Average lifetime of buildings: http://www.concrete.org.uk/fingertipsnuggets. asp? $\mathrm{cmd}=$ displaysid $=750$

Energy usage in the EU: https://ec.europa.eu/energy/en/topics/energyefficiency/buildings

Energy usage in the US: https://www.usgbc.org/articles/green-building-facts

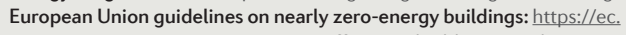
europa.eu/energy/en/topics/energy-efficiency/buildings/nearly-zeroenergy-buildings 